\title{
Vaccination Attitudes Among Patients with Cancer Receiving Chemotherapy
}

\author{
Serkan AKIN ${ }^{1}$, Omer DIZDAR ${ }^{2}$, Lale OZISIK ${ }^{3}$, Mine D. TANRIOVER ${ }^{3}$, Songul KAMISLI², \\ Mustafa ERMAN², Mutlu HAYRAN²
}

\author{
${ }^{1}$ Hacettepe University Cancer Institute, Department of Medical Oncology \\ ${ }^{2}$ Hacettepe University Cancer Institute, Department of Preventive Oncology \\ ${ }^{3}$ Hacettepe University School of Medicine, Department of Internal Medicine, Ankara, TURKEY
}

\begin{abstract}
Immunization against vaccine preventable diseases is an essential but mostly overlooked issue in oncology practice. We aimed to investigate the utilization of adult immunization recommendations and the perception of the patients with cancer receiving chemotherapy on immunization. A 15-item questionnaire about immunization in adults with cancer diagnosis was administered to patients with various cancers treated in daycare chemotherapy unit of Hacettepe University Cancer Institute. Total of 229 patients completed the survey. Fifty-four percent of patients were vaccinated at least once, most commonly against influenza and tetanus over 18 years old. Higher rate of participants was opposed to vaccination of patients with cancer diagnosis compared with those who were opposed to vaccination of healthy adults. Vaccination was never recommended in $93 \%$ of the participants. Only $9 \%$ of patients ( $n=21$ ) were shot after cancer diagnosis. There was a strong association between doctor's advice and vaccination status. Twelve of 15 patients (80\%) who were recommended to be vaccinated did so whereas only 9 of 214 remaining patients (4.2\%) were vaccinated. Among those not vaccinated after diagnosis of cancer, most frequent reason was; not recommended by the doctor. Neither vaccination rates nor perceptions on adult immunization differed by age, gender, marital status, presence of co-morbidity or type of cancer. Among adult patients with cancer and receiving chemotherapy, immunization rates were found to be very low. Main reason was the lack of recommendation by the primary physician involved in the treatment, mostly oncologist. Awareness on this issue in physicians, particularly oncologists, may increase vaccination rates.
\end{abstract}

Keywords: Adult immunization, Vaccine preventable disease, Cancer chemotherapy

\section{ÖZET}

\section{Kemoterapi Alan Kanser Hastalarının Aşı Davranışları}

Önlenebilir hastalıklara karşı aşılanma onkoloji pratiğinde inmal edilen bir konudur. Bu çalışmada kemoterapi alan kanser hastalarının erişkin aşılanması ile ilgili görüş ve algılarını, düşük aşlanma oranlarının nedenlerini araştırmayı amaçladık. Hacettepe Üniversitesi Onkoloji Hastanesi ayaktan tedavi ünitesinde çeşitli kanser tanıları ile kemoterapi almakta olan erişkin hastalara, erişkin aşılanması ile ilgili 15 sorudan oluşan bir anket uygulandı. Toplam 229 hasta anketi tamamladı. Hastaların \%74,7'si erişkinlerin de aşılanması gerektiğini düşünmekteydi. En sık influenza ve tetanos aşısı olmak üzere hastaların \%54'ü 18 yaşından sonra en az bir defa aşılanmıştı. Katıımcıların \%16,6'sı erişkinlerin aşılamasına karşıydı, daha yüksek oranda bir bölümü ise kanserli hastaların așılanmasına karşı olduklarını belirtti. Hastaların \%93'üne kanser tanısı aldıktan sonra hiç aşı önerilmemişti. Sadece 21 hastanın (\%9) tanı sonrası aşı yaptırdığı anlaşıııken en sık influenzaya karşı aşılanma görüldü. Doktor önerisi ve aşılanma durumu arasında anlamlı bir ilişki tespit edildi. Kendisine onkoloğu tarafından aşı önerilen 15 hastanın 12'si(\%80) aşılanırken, önerilmeyen 214 hastadan sadece 9'u (\%4,2) aşı yaptırmıştı. Hastaların tanı sonrası en sık aşı yaptırmama nedeni; doktorun önermemesi idi. Yaş, cinsiyet, medeni durum, ek hastalık varlığı ve kanser türü ile aşılanma sıklığı arasında bir ilişki gözlenmedi. Kemoterapi alan kanser hastalarında aşılanma oranları çok düşük bulundu. Bunun ana nedeninin hastanın tedavisinden sorumlu primer hekimin aşılanma için hastayı yönlendirmemesi ve hastaların yanlış önyargıları olduğu, hekim tarafından aşı önerildiğinde ise aşılanma oranının yükseldiği görüldü. Onkologların erişkin aşılama programı konusunda bilgilendirilmesi, farkındalığın artıııması ve endişelerinin giderilmesi, kanser hastalarının aşılanma oranlarını artırabilir.

Anahtar Kelimeler: Erişkin bağışıklaması, Aşı ile önlenebilen hastalıklar, Kanser kemoterapisi 


\section{INTRODUCTION}

Vaccine preventable diseases such as influenza and invasive pneumococcal infections give rise to thousands of adult deaths every year. Patients with cancer receiving chemotherapy are particularly vulnerable to infections because of their impaired immunity, however immunization rates in this patient group is quite low. ${ }^{1,2}$

Several international authorities including Infectious Diseases Society of America (IDSA), United States Advisory Committee on Immunization Practices (ACIP), Centers for Diseases Control and Prevention (CDC), and National Comprehensive Cancer Network (NCCN) have immunization recommendations for cancer patients under the heading of immunosuppression. ${ }^{3,4}$ However, real life immunization rates are low, far behind the success in pediatric immunization rates. In the US, for example, about $68 \%$ of those over 65 year of age were vaccinated for influenza in 2012 while Tdap (tetanus, diphtheria, acellular pertussis) vaccination rate among adults aged 19-64 years was only $15.6 \%$, HPV vaccination rate among women aged 19-26 years for 1 or more doses was $34.5 \% .^{5}$ The median vaccine coverage rate for influenza was 44.7\% among 31 European Union (EU) and Economic Area (EEA) countries, with only the Netherlands and the United Kingdom achieved the 75\% EU target. ${ }^{6}$ The figures were found much lower in a previous survey from Turkey exploring influenza and pneumococcal vaccination status. ${ }^{7}$ We herein investigated the employment of adult immunization recommendations and the perception of the patients on immunization among patients with cancer receiving chemotherapy.

\section{PATIENTS AND METHODS}

A survey about adult immunization was conducted in the daycare chemotherapy unit of Hacettepe University Cancer Institute among patients with cancer receiving chemotherapy. Patients were asked permission for completing survey regardless of their diagnosis, stage and chemotherapy. Thereafter agreed patients were underwent survey.

The questionnaire included demographic information including age, gender, marital status, occupation, educational status, diagnosis, date of the diagnosis and 15 items about vaccination. Patients were asked for their attitudes towards vaccination over 18 year-old and vaccination of cancer patients. Acceptability and refusal of patients about vaccination were noted. 'Why weren't you vaccinated?' was asked for understanding reasons of immunization. Among vaccinated patients, who proposed and which vaccines suggested were recorded. The data were gathered between July and September of 2015.

\section{Statistical Analysis}

Data collection and statistical analyses were performed with SPSS statistical software version 19.0. Patient demographics and responses to the questions were analyzed with descriptive statistics; chi square test was used to compare ratios. $P$ value $<0.05$ was considered statistically significant. Ethical permission for this study was obtained from Hacettepe University Ethics Commission.

\section{RESULTS}

A total of 229 patients completed the survey. The median age was 56 (min: 22, max: 83) and 124 $(54.1 \%)$ were female. Most frequent cancer types were breast and colorectal cancers $(28.8 \%$ and $18.3 \%$, respectively). Baseline characteristics of patients are summarized in Table 1.

Participants were asked about their perception on adult vaccination and $74.7 \%$ told that people over 18 years of age must be vaccinated. Influenza, pneumococci, tuberculosis, tetanus and hepatitis vaccines were listed as indicated ones. On the other hand, $16.6 \%$ told that vaccination is not indicated in adults since they believed that vaccination was not necessary in adults (35\%) or it may be even harmful (23\%). Some patients had no idea about necessity of adult vaccination (8.7\%). Higher rates of participants thought that vaccination of healthy adults is more appropriate than vaccination of patients with cancer diagnosis (32.3\% vs. $16.6 \%$, p < $0.001)$. The most frequent reason was the concerns of being harmful for the patients (40\%). Interestingly, patients who had higher educational status (i.e. university graduate) had higher rate of opposition to vaccination after the diagnosis of cancer compared with those with lower educational status $(\mathrm{p}=0.03)$. 
Table 1. Baseline characteristics of study population

\begin{tabular}{|c|c|c|}
\hline Variables & $\mathbf{n}$ & $\%$ \\
\hline \multicolumn{3}{|l|}{ Gender } \\
\hline Female & 124 & 54.1 \\
\hline Male & 105 & 45.9 \\
\hline \multicolumn{3}{|l|}{ Cancer types } \\
\hline Breast & 66 & 28.8 \\
\hline Gastrointestinal & 71 & 31.0 \\
\hline Hematological & 27 & 11.8 \\
\hline Lung & 22 & 9.6 \\
\hline Genitourinary & 19 & 8.3 \\
\hline Others & 24 & 10.4 \\
\hline \multicolumn{3}{|l|}{ Marital status } \\
\hline Married & 190 & 83.0 \\
\hline Single & 39 & 17.0 \\
\hline \multicolumn{3}{|l|}{ Educational status } \\
\hline Primary school & 64 & 27.9 \\
\hline Secondary school & 30 & 13.1 \\
\hline High school & 45 & 19.7 \\
\hline College & 90 & 39.3 \\
\hline \multicolumn{3}{|l|}{ Time of diagnosis } \\
\hline$<6$ months & 96 & 41.9 \\
\hline 6-12 months & 57 & 24.9 \\
\hline$>12$ months & 76 & 33.2 \\
\hline
\end{tabular}

Vaccination was never recommended to $93 \%$ of the participants. Among 15 patients who were recommended vaccination, 8 were advised by an oncologist, 1 was advised by a family doctor, pharmacist or a friend. Influenza was the most frequently recommended vaccine, pneumococcal and hepatitis B vaccinations were recommended to few patients.

Over 18 years old, $54 \%$ of patients were vaccinated at least once, most commonly against influenza $(25.3 \%)$, tetanus $(22.3 \%)$, hepatitis $(13.5 \%)$, and pneumococci $(7.4 \%)$. Two percent of patients $(\mathrm{n}=$ 4) were vaccinated by necessity during military services or before pilgrimage.

Only $9 \%$ of patients $(n=21)$ received a vaccine shot after cancer diagnosis. Influenza, pneumococcal, hepatitis, varicella and tetanus vaccines were administered to $17,4,3,1$ and 1 patients, respectively. There was a strong association between doctor's advice and vaccination status. Twelve of 15 patients $(80 \%)$ who were recommended to be vaccinated did so whereas only 9 of 214 remaining patients $(4.2 \%)$ were vaccinated $(\mathrm{p}<0.001)$. The reasons of not being vaccinated expressed by the patients were as follows; not receiving a recom- mendation from the treating physician for vaccination after diagnosis of cancer $(64.9 \%)$, perceiving the vaccine as unnecessary (17.8\%), lack of information $(8.2 \%)$, fear of adverse effects $(4.2 \%)$, considering the vaccine ineffective $(2.9 \%)$, religious belief $(1 \%)$ and other $(1 \%)$.

Finally, participants were asked whether they were vaccinated within last year. Eleven and nine percent of the participants were vaccinated against influenza and pneumococcal pneumonia, respectively. Neither vaccination rates nor perceptions on adult immunization differed by age, gender, marital status and presence of comorbid diseases or type of cancer.

\section{DISCUSSION}

This present survey questioned perceptions for vaccination and rates of immunization against vaccine preventable diseases in patients receiving chemotherapy. We showed that vaccination rate based on adult immunization guidelines was very low. Main reason for this was identified as the lack of recommendation by the primary treating physician, particularly the oncologist.

Infections in immunosuppressed adults have a high risk of mortality as well as severe complications, which require complex care with a high cost burden. These infections and complications may cause delay and even failure in the scheduled administration of chemotherapy and deteriorate treatment outcomes. Risk of death from influenza in cancer patients older than 65 years old was estimated as 166 per 100000 in US.8 Patients with lung cancer or multiple myeloma had $9 \%$ and $12 \%$ mortality rate from seasonal influenza, respectively. ${ }^{8}$ It was estimated that influenza hospitalizations alone cost the US health care system about $\$ 8.3$ billion annually. ${ }^{9}$ On the other hand, vaccination significantly reduces morbidity and mortality associated with these infections. A recent Cochrane analysis including one randomized controlled trial and 3 observational studies showed lower mortality rate with influenza vaccination in immunosuppressed adults with cancer. Confirmed influenza and pneumonia rates were lower with vaccination, and a reduction in hospitalizations following vaccination was observed..$^{10}$ Another prospective cohort study showed Influenza vaccination was associated with lower mortality among adult cancer patients. ${ }^{11}$ 
In spite of these favorable outcomes with immunization, coverage rates for these vaccines in adults are markedly lower than the rates among children and far below adult immunization goals. Only 9\% of the patients were vaccinated after cancer diagnosis in our study. Reported rates of vaccination in other studies showed various figures. An Austrian study showed influenza vaccination rate as $22 \%$ amongst patients with hematological malignancies and $13 \%$ amongst patients with solid tumors. ${ }^{12}$ Influenza vaccine coverage was $45 \%$ in adult cancer patients in US, with increasing rates among elderly and those with higher income. ${ }^{13}$ A previous study in cancer patients from Turkey showed overall vaccination rate as $17 \%$ and $4.2 \%$ for influenza and pneumococci, respectively. ${ }^{7}$

Main reason for denial of vaccination in our study was the lack of acknowledgement by the treating physician as reported by patients. Adult immunization was not embraced by physicians' as much as pediatric immunization. In a survey of immunization among patients with high-risk conditions, the most common reason for not being vaccinated was not being offered or not knowing the vaccine was needed. ${ }^{14}$ Ninety three percent of the patients in our study were never recommended for vaccination and vaccination rate was substantially higher when offered by the oncologist (80\% vs. $4.2 \%)$. Vinograd et al from Israel also showed that recommendations from the oncologist were the strongest predictor for vaccination (OR 10.7, 95\% CI 5.421.2). ${ }^{15}$ However, many patients with high-risk conditions are seen by subspecialists, and subspecialists are less likely to recommend influenza vaccination than general practitioners. ${ }^{16}$ In oncology setting, treatment of cancer and struggling with associated toxicities might dominate and other supportive and preventive issues including vaccination might be underappreciated or ignored. Oncologists from Korea were asked about vaccination of their patients against H1N1. Influenced recommendation rate was only $22.6 \% .{ }^{17}$ The optimum way is to engage all healthcare providers in offering vaccination at every "oppurtunity", i.e. clinic visits, inpatient encounters etc. A guideline implementation study was associated with a significant increase in the rate of pneumococcal vaccination (47 vs. $25 \%$, $\mathrm{P}=0.0018)$ in a tertiary cancer center. ${ }^{18} \mathrm{~A}$ continuous medical education program using live meetings, patient handouts, posters web based applica- tions and organized by an interdisciplinary steering committee significantly improved immunization rates of patients and medical staff.

Vaccination recommendations of ACIP in patients with cancer are depicted in Table 2. Confusion related to differing vaccination schedules for various subpopulations is noted as one of the barriers to adult immunization. A more simplified and convenient immunization schedule might also help physicians adopt immunization recommendations to their daily clinical practice. Liability and compensation concerns are also limitations for widespread vaccination in some parts of the world. For example in US, there is no large public sector payer for adults less than $65 \mathrm{y}$ of age, coverage is almost exclusively through private payers. In Turkey, the Social Security System pays for annual influenza vaccine and polysaccharide pneumococcal vaccine when the chronic disease and immunosuppression are declared by a doctor report.

Some of the patients in our study thought that vaccines are not indicated in adulthood considering them ineffective or even harmful. Live vaccines, as a rule, are generally accepted as contraindicated in immunosuppressed patients. Effectiveness and safety of vaccines in cancer patients have been studied in mostly underpowered studies that included patients with various cancers and treatment regimens and definition of vaccine response was not uniform. Vaccine response rates are generally lower in patients with hematological malignancies compared to those with solid tumors. 4 A recent meta-analysis showed lower rates of seroconversion for seasonal influenza A (H1N1), A (H3N2) and B but similar level of clinical protection against influenza with vaccination while toxicity was similar with immunocompetent controls. ${ }^{19}$ In general, inactivated vaccines should be given at least 2 weeks before the initiation of chemotherapy to maximize the immune response. Although antibody responses are suboptimal, vaccination with inactivated vaccines is crucial given the similar level of clinical protection and favorable risk- benefit profile. For patients who are undergoing chemotherapy, administration of the vaccine is recommended 2 weeks before or 2 weeks after chemotherapy or between chemotherapy cycles, and trying to avoid giving the vaccine when the patients' white blood cell counts are at their nadir. ${ }^{4}$ Additionally it is criti- 


\section{International Journal of Hematology and Oncology}

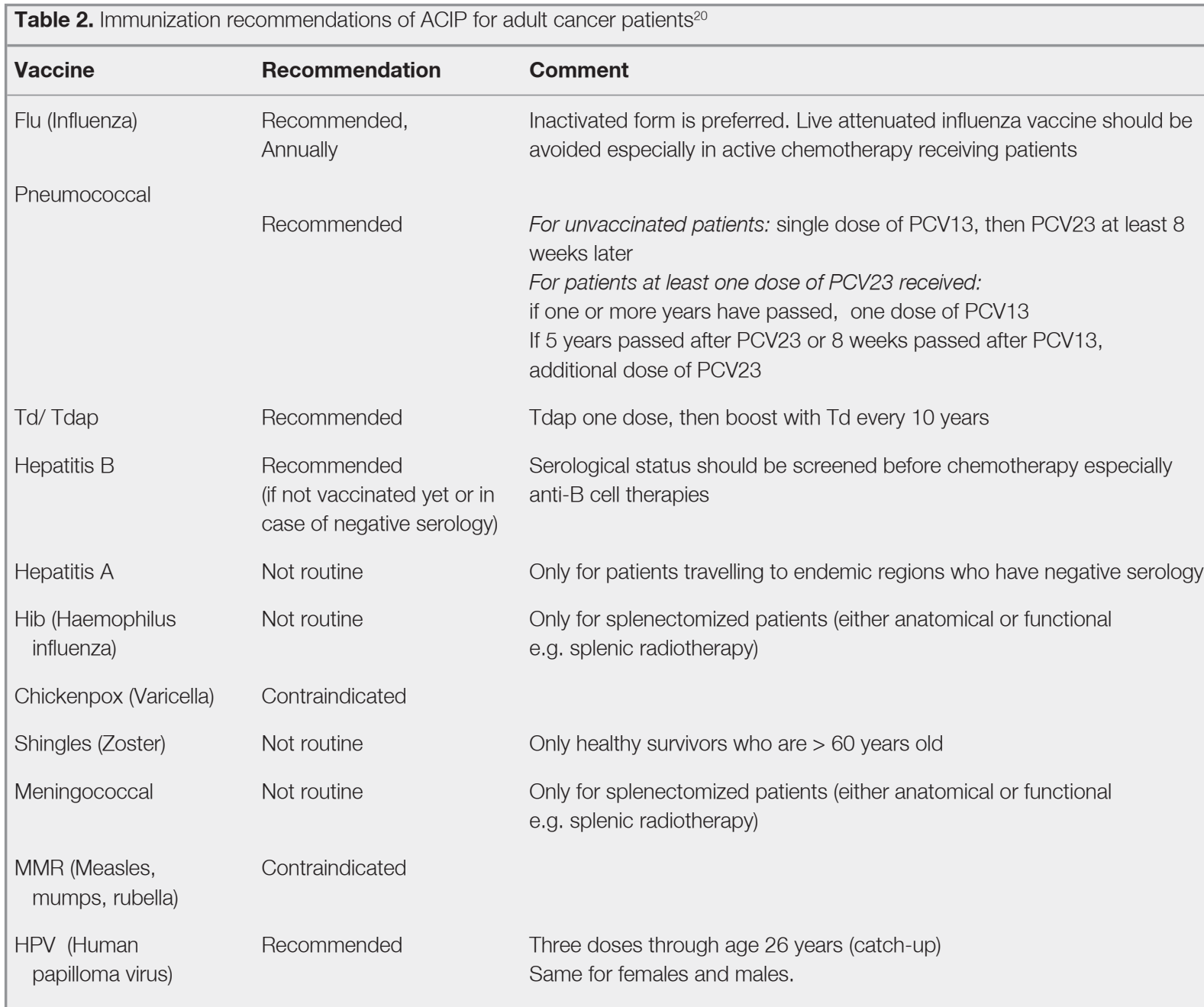

cal that healthy household contacts of immunosuppressed persons be vaccinated to reduce the chance of exposure to vaccine preventable diseases, bearing in mind that live vaccines in close contacts of immunosuppressed patients may also pose a risk of infection. ${ }^{20}$

Effective institutional strategies for promoting vaccine delivery should be implemented. Posters, patient handouts, web based tools and educational activities may significantly increase the health literacy of the patients and thereby the immunization rates to achieve the goals. Not only oncologist, but also other health care providers including family doctors, internists should collaborate to be involved in immunization practice of cancer patients. A vigorous adult immunization infrastructure should be implemented as part of a national immunization program.
In conclusion, vaccination against infections is an important issue of preventive care in cancer patients. Although inactivated vaccines are safe and generally effective, they are underused. Physicians, particularly the oncologists have a critical role in the recommendation and delivery of vaccinations to their patients. Every opportunity should be used to advise patients for vaccination and patients should be informed and reassured regarding the efficacy and safety of immunization.

\section{Acknowledgement}

The abstract of this research was presented orally in 6. Turkish Medical Oncology Congress and took best oral presentation award. 


\section{REFERENCES}

1. Meidani M, Rostami M, Dehghani F. Why coverage of influenza vaccine is not enough in patients receiving chemotherapy? International Journal of Preventive Medicine 2: 186-187, 2011.

2. Loulergue P, Mir O, Alexandre J, et al. Low influenza vaccination rate among patients receiving chemotherapy for cancer. Annals of Oncology 19: 1658, 2008.

3. Denlinger CS, Ligibel JA, Are M, et al. Survivorship: immunizations and prevention of infections. Journal of the National Comprehensive Cancer Network 12: 1098-1111, 2014.

4. Ariza-Heredia EJ, Chemaly RF. Practical review of immunizations in adult patients with cancer. Human Vaccines \& Immunotherapeutics 11: 2606-2614, 2015.

5. Williams WW, Lu PJ, O'Halloran A, et al. Noninfluenza vaccination coverage among adults - United States, 2012. MMWR Morbidity and Mortality Weekly Report 63: 95-102, 2014.

6. European Centre for Disease Prevention and Control. Seasonal influenza vaccination in Europe - Overview of vaccination recommendations and coverage rates in the EU Member States for the 2012-13 influenza season. Stockholm: ECDC; 2015.

7. Urun Y, Akbulut H, Demirkazik A, et al. Perception about influenza and pneumococcal vaccines and vaccination coverage among patients with malignancies and their family members. Journal of BUON 18: 511-515, 2013.

8. Cooksley CD, Avritscher EB, Bekele BN, et al. Epidemiology and outcomes of serious influenza-related infections in the cancer population. Cancer 618-628, 2005.

9. Molinari NA, Ortega-Sanchez IR, Messonnier ML, et al. The annual impact of seasonal influenza in the US: measuring disease burden and costs. Vaccine 25: 5086-5096, 2007.

10. Eliakim-Raz N, Vinograd I, Zalmanovici Trestioreanu A, et al. Influenza vaccines in immunosuppressed adults with cancer. The Cochrane Database of Systematic Reviews; 10: CD008983, 2013.

11. Vinograd I, Eliakim-Raz N, Farbman L, et al. Clinical effectiveness of seasonal influenza vaccine among adult cancer patients. Cancer 119: 4028-4035, 2013.

12. Poeppl W, Lagler $H$, Raderer $M$, et al. Influenza vaccination perception and coverage among patients with malignant disease. Vaccine 33: 1682-1687, 2015.

13. Bridges CB, Hurley LP, Williams WW, et al. Meeting the Challenges of Immunizing Adults. Vaccine 33. 4: D114-120, 2015.
14. Singleton JA, Wortley P, Lu PJ. Influenza vaccination of persons with cardiovascular disease in the United States. Texas Heart Institute Journal 31: 22-227, 2004.

15. Vinograd I, Baslo R, Eliakim-Raz N, et al. Factors associated with influenza vaccination among adult cancer patients: a case-control study. Clinical Microbiology and Infection 20: 899-905, 2014.

16. Nichol KL, Zimmerman R. Generalist and subspecialist physicians' knowledge, attitudes, and practices regarding influenza and pneumococcal vaccinations for elderly and other high-risk patients: a nationwide survey. Archives of Internal Medicine 161: 2702-2708, 2001.

17. Shin DW, Kim Y, Park JH, et al. Practices and predictors of $2009 \mathrm{H} 1 \mathrm{~N} 1$ vaccination in cancer patients: a nationwide survey in Korea. Influenza and Other Respiratory Viruses; 6: e120-128, 2012.

18. Toleman MS, Herbert K, McCarthy $\mathrm{N}$, et al. Vaccination of chemotherapy patients-effect of guideline implementation. Supportive Care in Cancer 24: 2317-2321, 2016.

19. Beck CR, McKenzie BC, Hashim AB, et al. Influenza vaccination for immunocompromised patients: systematic review and meta-analysis from a public health policy perspective. PloS One 6: e29249, 2011.

20. General Recommendations on Immunization Epidemiology and Prevention of Vaccine-Preventable Diseases The Pink Book: Course Textbook - 13th Edition, Washington D.C. Public Health Foundation, 2015.

\section{Correspondence}

Dr. Serkan AKIN

Hacettepe Üniversitesi

Onkoloji Enstitüsü

Tibbi Onkoloji Anabilim Dali

06100 Altindag

ANKARA / TURKEY

Tel: (+90-312) 3052936

Fax: (+90-312) 3052935

e-mail: drserkanakin@gmail.com 